\title{
ERITROCITOZĖS PASIREIŠKIMAS ŠIRDIES NEPAKANKAMUMU SERGANČIAM PACIENTUI. KLINIKINIS ATVEJIS
}

\author{
Alma Neniškiené $\dot{e}^{1,2}$, Edita Taparauskiené $\dot{e}^{1,2}$, Neringa Taparauskaité2 \\ ${ }^{1}$ Kauno klinikine ligonine, ${ }^{2}$ Lietuvos sveikatos mokslu universiteto Medicinos akademija
}

Raktažodžiai: eritrocitozè, tikroji policitemija, antrinè eritrocitozè.

\begin{abstract}
Santrauka
Eritrocitozė yra apibrèžiama kaip būklè, kurios metu padidèja eritrocitų kiekis. Hemoglobinas paprastai būna daugiau negu $165 \mathrm{~g} / 1$ moterims ir $185 \mathrm{~g} / \mathrm{l}$ vyrams, hematokritas daugiau negu 48 proc. moterims ir 52 proc. vyrams. Eritocitozė gali būti santykinè ar absoliuti, pirminè ar antrinè. Klinikinejje praktikoje svarbu įvertinti, kad širdies ydos, plaučių bei inkstų ligos, navikai gali sąlygoti eritrocitozès, sunkinančios paciento būklę, atsiradimą. Eritrocitozė gali daryti itaką trombozèms, širdies nepakankamumui pasireikšti, todèl svarbu laiku ją nustatyti ir gydyti.

Pateikiamas 34 metų paciento, stacionarizuoto dèl ịtariamo tromboflebito arba rožès, klinikinis atvejis. Pacientas prieš metus sirgo miokardo infarktu, buvo diagnozuotas lètinis širdies nepakankamumas. Atlikus bendrą kraujo tyrimą nustatytas padidejjęs eritrocitu kiekis, hemoglobinas, hematokritas, diagnozuota eritrocitozè. Išsiaiškinta, kad eritrocitozè pacientui buvo nustatyta prieš metus, pacientas medikamentų nevartojo. Vyraujant širdies nepakankamumo požymiams itariama antrinè eritrocitozè.
\end{abstract}

\section{Ivadas}

Esant eritrocitozei, padideja eritrocitų kiekis, hemoglobinas ( $>165 \mathrm{~g} / \mathrm{l}$ moterims ir $>185 \mathrm{~g} / \mathrm{l}$ vyrams), hematokritas ( $>48$ proc. moterims ir $>52$ proc. vyrams) [1]. Eritrocitozè gali būti santykinè ir absoliuti.

Santykinè eritrocitozè pasireiškia sumažejus kraujo plazmos tūriui dèl dehidratacijos, vartojant diuretikus [2].

Absoliuti eritrocitozè skirstoma ị pirminę ir antrinę. Pirminès eritrocitozės metu veša kraujo ląstelių pirmtakai. Antrinè eritrocitozè pasireiškia dèl padidejusio eritropoetino kiekio. Jo kiekis gali padidèti kaip kompensacinis atsakas dèl sisteminès hipoksijos, lètinių širdies, plaučių, inkstų ligu [3].

Apie 50 proc. atvejų eritrocitozè pasireiškia dèl šaluti- nès ne hematologinès patologijos [1]. Nustačius eritrocitozę svarbu išsiaiškinti, ar eritrocitozė yra santykine, ar absoliuti, pirminè ar antrinè, nes nuo to priklauso gydymo taktika. Tikroji policitemija gydoma taikant flebotomijas, mielosupresinị gydymą [4]. Gydant antrinę eritrocitozę, svarbu gydyti pagrindinę ligą, taip pat taikomos flebotomijos, gali būti reikalinga oksigenoterapija [5]. Diferencinei diagnostikai svarbus klinikinių požymių, šalutinių patologijų įvertinimas, eritropoetino kiekio nustatymas, deguonies saturacija, viršutinio pilvo aukšto echoskopija, JAK-2 mutacijos nustatymas [3].

Darbo tikslas: pristatyti klinikinį atvejị ir aptarti mokslinès literatūros duomenis apie eritrocitozę, pirminès ir antrinès eritrocitozės pasireiškimą bei diferencinę diagnostiką.

\section{Klinikinis atvejis}

34 metu pacientas M. Ž. šeimos gydytojo siuntimu pateko ị LSMUL KK skubios pagalbos skyrių dèl kapšelio sutinimo ir skausmo, kojų patinimo ir paraudimo. Atlikti kraujo tyrimai: leukocitai - $6,15 \times 10^{9} / 1$, neutrofilai $-52,1 \%$, limfocitai - $28 \%$, monocitai - $17,1 \%$, eozinofilai - $2,1 \%$, bazofilai - 0,7\%, eritrocitai - $6,03 \times 10^{12} / 1$, hemoglobinas - 194 $\mathrm{g} / \mathrm{l}$, hematokritas $-58,4 \%, \mathrm{MCV}-96,8 \mathrm{fl}, \mathrm{MCH}-32,2 \mathrm{pG}$, MCHC - $332 \mathrm{~g} / 1$, RDW - 16,3\%, trombocitai - $180 \times 10^{9} / 1$, CRB - 51,96 mg/l, gliukozè- 4,56 mmol/1, kreatininas - 59 $\mu \mathrm{mol} / \mathrm{l}$, šlapalas $-1,2 \mathrm{mmol} / \mathrm{l}$, kalis $-4,3 \mathrm{mmol} / 1$, natris $145 \mathrm{mmol} / \mathrm{l}$. Atliktas skubus kojų venų ultragarsinis tyrimas: abipus kojose ryški poodinių minkšųų audinių edema, dèl ryškios edemos šlauninès venos abipus matomos tik viršutiniame trečdalyje, spūdžios, kraujotaka registruojama; pakinklinè vena spūdi, kraujotaka registruojama. Ultragarsinio tyrimo metu kapšelio poodiniai minkštieji audiniai ryškiai edemiški, tarp dangalų matomi iki $0,5 \mathrm{~cm}$ storio skysčio ruoželiai, ribotų skysčio sankaupų nematyti, abipus sėklidès homogeniškos, kraujotaka registruojama. Konsultavus chirurgui, ịtarta abiejų kojų rožè, rekomenduotas tolimesnis gydymas infekcinių ligų ar dermatologijos skyriuje.

Pacientas GMP pervežtas ị KKL priemimo skyrių, konsultuotas infektologo. Edemos kojose palaipsniui progre- 
suoja apie 2 mėnesius, vargina dusulys fizinio krūvio metu. Hemoglobinas per $180 \mathrm{~g} / 1$ yra metus laiko, prieš ménesi dẻl ịtariamos PATE daryta krūtinès ląstos KT - PATE nepatvirtinta. Prieš metus pacientas sirgo miokardo infarktu, ambulatoriškai skirtų medikamentų nevartojo, rūko, saikingai vartoja alkoholi. Apžiūros metu rasta: pacientas hipersteninès kūno sandaros (KMI $32 \mathrm{~kg} / \mathrm{m}^{2}$ ), oda ir gleivinès raudonai cianozinio atspalvio. Ryški edema kojose, kapšelyje ir apatinejje pilvo sienos dalyje. Širdies veikla ritmiška, ŠSD - 100 k./min., AKS - 126/80 mmHg, KD - 18 k./min. Plaučiuose alsavimas vezikulinis, apatinèse dalyse abipus išklausoma drègnų karkalų. $\mathrm{SpO}_{2}$ be papildomo deguonies $82 \%$. Temperatūra $-37,5^{\circ} \mathrm{C}$. Vyraujant kardiopulmoninio nepakankamumo požymiams, pacientas tolimesniam ištyrimui ir gydymui stacionarizuotas ị vidaus ligų diagnostikos skyrių. Negalint atmesti bakterinès odos infekcijos, rekomenduotas antibakterinis gydymas cefazolinu ị veną.

Pacientas stacionarizuotas ị vidaus ligų diagnostikos skyrių. Atliktas troponino I tyrimas dèl EKG stebimų bifazių $\mathrm{T} \mathrm{V}_{1-3}$ derivacijose. Troponinas I - 0,033 $\mu \mathrm{g} / \mathrm{l}$ (neigiamas). Budinčio gydytojo preliminari diagnozė: IŠL. Senas MI. Stabili 2 kl. KA. III lètinis ŠN. Diferencijuojama kojų rožè ir tromboflebitas. Skirtas gydymas ilgo veikimo nitratais, kilpiniais diuretikais per os ir į veną, cefazolinu 4 g per parą ị veną.

Dèl stebètos eritrocitozès pacientas konsultuotas hematologo. Vyraujant širdies nepakankamumo požymiams ịtariama antrinè eritrocitozè, patarta neskirti hidroksikarbamido, tęsti širdies nepakankamumo gydymą diuretikais, gydymą papildyti aspirinu, ligoni nukreipti planinei hematologo koncultacijai.

Po 13 valandu gydymo stacionare pacientas eidamas staiga nukrito. Gydytojo konstatuota klinikinè mirtis, pradètas gaivinimas, vèliau tęstas reanimacinès komandos. Gaivinimas buvo efektyvus, EKG - sinusinis ritmas, ventiliuojant DPV aparatu, pacientas pervežtas i suaugusiųu intensyvios terapijos ir reanimacijos skyrių. Rentgenologiškai diagnozuoti polisegmentiniai infiltraciniai pakitimai dešiniajame plautyje, skystis pleuros ertmèje abipus, plaučiu edema. Biocheminiame kraujo tyrime: D - dimerai - 2,67 $\mu \mathrm{g} / \mathrm{ml}, \mathrm{B}$ - natiruretinis peptidas - $378 \mathrm{pg} / \mathrm{ml}$, CRB - 270,1 $\mathrm{mg} / \mathrm{l}$, kita - norma. Atlikta bronchoskopija, bronchų išplovų ir kraujo pasèliuose bakterijų augimo neaptikta. Atlikus krūtinès ląstos KT duomenų už masyvią PATE nepakako. Pilvo organų echoskopija be pakitimų. Antibakterinis gydymas cefozolinu keistas ị ceftriaksoną $2 \mathrm{~g} 2 \mathrm{k}$./d. ị veną (iš viso $68 \mathrm{~g}$ ) ir gentamiciną $240 \mathrm{mg} 1 \mathrm{k} . / \mathrm{d}$. ị veną (iš viso $3,36 \mathrm{~g}$ ). 10 dienų skirti kilpiniai diuretikai, visą laiką skirtas mažos molekulinès masès heparinas Fraxiparine.

Per 14 gydymo SRITS parų paciento būklè stabilizavosi.
Diurezè svyravo 2,6 - 8 1/p., paciento svoris sumažèjo 12 kilogramų, išnyko edemos pilve, kapšelyje ir kojose, rezorbavosi infiltraciniai pakitimai plaučiuose, skystis pleuros ertmėje. Perkèlus ị vidaus ligų diagnostikos skyrių, toliau tęstas antibakterinis gydymas, skirtas torazemidas $20 \mathrm{mg} 1$ k./d. per os, spironolaktonas $100 \mathrm{mg} 1 \mathrm{k} . / \mathrm{d}$. per os, rivaroksabanas $20 \mathrm{mg} 1 \mathrm{k} . / \mathrm{d}$. per os, kineziterapija. Funkciniais kvèpavimo mėginiais nustatyta $\mathrm{I}^{\circ}$ restrikcija ir vidutinių bei stambių bronchų pralaidumo sutrikimas. Žymiai sumažèjo kvėpavimo funkcijos nepakankamumo ir širdies nepakankamumo požymiai, CRB sumažèjo iki $20,6 \mathrm{mg} / \mathrm{l}$, paciento oda išliko raudonai violetinio atspalvio. Kraujo tyrime: eritrocitu - $6,78^{*} 10^{12} / 1$, hemoglobinas $-206 \mathrm{~g} / \mathrm{l}$, hematokritas $-64,5 \%$, leukocitu - 8,3 x10 $/ 1$, trombocitu - $186 \times 10^{9} / 1$.

Po 21 paros gydymo stacionare pacientas išrašytas nukreipiant skubiai hematologo konsultacijai dèl ryškios eritrocitozès, indikacijų flebotomijai.

\section{Diskusija}

Eritrocitozė yra apibréžiama kaip būklè, kurios metu padidèja eritrocitų kiekis. Hemoglobinas paprastai būna daugiau negu $165 \mathrm{~g} / 1$ moterims ir $185 \mathrm{~g} / 1$ vyrams, hematokritas daugiau negu 48 proc. moterims ir 52 proc. vyrams [1]. Skiriama santykinè ir absoliuti eritrocitozè.

Santykinė eritrocitozė pasireiškia sumažéjus kraujo plazmos tūriui dèl dehidratacijos, vartojant diuretikus. Tuomet nèra stebimas ląstelių skaičiaus padidejimas, tačiau pastoviai sumažèjęs plazmos tūris gali turèti ịtakos kraujo klampumui, tèkmei ir audinių aprūpinimui krauju [2].

Absoliuti eritrocitozè skirstoma į pirminę ir antrinę. Tikroji policitemija - tai pirminè igyta eritrocitozè, kurios metu dèl mutacijos kamieninèje kraujodaros ląstelèje kaulų čiulpuose veša kraujo ląstelių pirmtakai. Jos metu padidèja ne tik eritrocitu, hemoglobino kiekis bei hematokritas, bet ir trombocitų bei neutrofilinių granulocitų kiekis - tai nustatoma maždaug pusei sergančiųų tikraja policitemija [6].

Apie 50 proc. atvejų eritrocitozė pasireiškia dèl gretutinès ne hematologinès patologijos [1]. Antrinè eritrocitozė dažniausiai pasireiškia dèl padidejjusio eritropoetino kiekio. Jo kiekis gali padidèti kaip kompensacinis atsakas dèl sisteminès hipoksijos, esant lètinèms plaučių ligoms, širdies ydoms (Falo tetrada, atviras arterinis latakas), hipoventiliacijai dèl miego apnèjos, taip pat sergant inkstų ligomis: inkstų policistoze, hidronefroze [3]. Didelę įtaką eritrocitozei atsirasti turi rūkymas [3]. Eritropoetinas skatina eritropeozę, taip stengiamasi užtikrinti pakankamą audinių aprūpinimą deguonimi. Eritropoetino kiekio padidejimas taip pat gali pasireikšti dẻl navikų: hepatoceliulinès karcinomos, inkstų navikų, smegenèlių hemangioblastomos, meningiomos ir kitų [7]. 
Europoje sergamumas pirmine absoliučia eritrocitoze remiantis skirtingais registrais varijuoja nuo 0,4 iki 2,8 atvejų 100 tūkst. gyventojų [8]. Antrinès absoliučios eritrocitozès atvejai yra dažnesni, tačiau tikslų paplitimą sunku ịvertinti.

Tikraja policitemija sergantys pacientai gali neturèti nusiskundimų, tačiau gali pasireikšti nuovargis, odos niežulys, dusulys, galvos svaigimas, regos sutrikimai, eritromelalgija. Gali būti trombozè, kraujavimas, splenomegalija, pletora [6]. Pacientai, kuriems nustatoma antrinè eritrocitozé, dažniausiai neturi ryškių nusiskundimų, tačiau dèl padidejjusio kraujo klampumo bei eritrocitų kiekio gali pasireikšti simptomai, susiję su išemija bei tromboze [9]. Pacientai skundžiasi nuovargiu, silpnumu, galvos ir krūtinès skausmu [1]. Dažniausiai dominuoja pagrindinès ligos simptomatika [6].

Tikroji policitemija diagnozuojama remiantis didžiaisiais ir mažaisiais kriterijais. Didieji kriterijai yra hemoglobinas vyrams daugiau $185 \mathrm{~g} / 1$, moterims $165 \mathrm{~g} / 1$ ir JAK-2 mutacija. Mažieji: nustatyta visų trijų hematopoezès eilių hiperplazija atlikus kaulų čiulpų biopsiją, sumažejęs eritropoetino kiekis serume bei endogeninių eritroidinių kolonijų formavimasis in vitro [10].

Antrinès eritrocitozès diagnostikai svarbi detali anamnezè ir klinikinis ištyrimas, siekiant išsiaiškinti eritrocitozès priežastị. Svarbu įvertinti paciento trombozių anamnezę, miego apnèjos pasireiškimą, lètines kvèpavimo sistemos ligas, galinčias lemti lètinę hipoksemiją, širdies ydas, inkstų ligas, rūkymą, medikamentų (tirozinkinazès inhibitorių, androgenų) vartojimą [1].

Eritrocitozès priežastị galima diferencijuoti pagal eritropoetino kiekị. Pirminei eritrocitozei būdingas sumažėjęs, o antrinei dèl hipoksijos - padidejjęs eritropoetino kiekis [5]. Taip pat svarbu nustatyti JAK-2 mutaciją, kuri yra vienas iš didžiųjų tikrosios policitemijos diagnostikos kriterijų. İtariant eritrocitozę dèl inkstų ar kepenų navikų, atliekama viršutinio pilvo aukšto echoskopija ir biocheminiai tyrimai. İtariant eritrocitozę dèl esančios hipoksijos, matuojama deguonies saturacija. Arterinio kraujo $\mathrm{pO}_{2}<80 \mathrm{mmHg}$ ir $\mathrm{O}_{2}$ saturacija $<90-95$ proc. yra būdinga antrinei eritrocitozei dèl hipoksijos [3].

Pirminès ir antrinès eritrocitozès komplikacijos yra panašios: trombozè, širdies nepakankamumas [5]. Nustatyta, kad antriné eritrocitozė yra svarbus faktorius venų trombozei atsirasti, kai kartu yra kiti rizikos veiksniai, pavyzdžiui, nutukimas [11]. Tikroji policitemija gali komplikuotis mielofibroze ir ūmine leukemija [4].

Pirminès ir antrinès eritrocitozės gydymas skiriasi. Tikroji policitemija gydoma atsižvelgiant į trombozių atsiradimo riziką. Pacientams, kurie turi mažą trombozių atsiradimo riziką, dažniausiai skiriamos flebotomijos bei aspirinas, tačiau didelès rizikos pacientams kaip pirmo pasirinkimo gydymas skiriamas ir hidroksikarbamidas arba interferonas alfa [4]. Nustačius, kad tikrajai policitemijai atsirasti svarbi JAK-2 mutacija, atrastas JAK1/JAK2 inhibitorius ruksolitinibas [3]. Jis gali būti skiriamas kaip antro pasirinkimo gydymas didelès rizikos pacientams, esant masyviai splenomegalijai arba jei hidroksikarbamidas yra neveiksmingas ar netoleruojamas [12].

Gydant antrinę eritrocitozę, atsiradusią dèl hipoksijos, svarbu pasirinkti gydymą, kuris užtikrintų tiek adekvatų audinių aprūpinimą deguonimi, tiek normalų kraujo klampumą [13]. Oksigenoterapija gali būti taikoma, kai eritrocitozè yra sukelta plaučių ligų. Taip pat svarbu gydyti pagrindinę ligą.

Vienas svarbiausių eritrocitozès gydymo būdų - flebotomija. Šis metodas taikomas pirminès eritrocitozès gydymui, o antrinè eritrocitozė gydoma taikant šį būdą, jei ji yra atsiradusi dèl lètinių plaučių ligų ar širdies ligų [14]. Antrinès eritrocitozės atveju indikacijos flebotomijai ir tikslinis hematokritas priklauso nuo pagrindinès ligos [5]. Plaučiu ligomis sergantys pacientai, kuriems pasireiškia simptomai, susiję su padidèjusiu kraujo klampumu, arba hematokritas yra didesnis nei 56 proc., turètų būti gydomi taikant flebotomiją, kad hematokritas būtų sumažintas iki 50-52 proc. [14] Gydant sergančius širdies ligomis reikia atsižvelgti ị simptomų pasireiškimą - pilvo, krūtinès skausmą, nuovargi, silpnumą, galvos skausmą, sutrikusị regejjimą. Šiems pacientams dažnai reikalinga izovoliuminè flebotomija bei geležies preparatų skyrimas [15]. Tikslinis hematokritas šiems pacientams priklauso nuo individualaus atvejo. Be tradicinès flebotomijos, taikoma ir eritrocitoaferezè. Metodas leidžia pašalinti reikiamą kiekį eritrocitų, nekeičiant kraujo tūrio. Taip pat antrinei eritrocitozei esant širdies ydoms gydyti yra aprašytas ir gydymas hidroksikarbamidu, kuris dažniausiai vartojamas tikrajai policitemijai gydyti vyresnio amžiaus pacientams [16].

\section{Išvados}

1. Dažnai eritrocitozė pasireiškia dèl šalutinès ne hematologinès patologijos.

2. Klinikinèje praktikoje svarbu ịvertinti, kad širdies ydos, nepakankamumas, plaučių bei inkstų ligos, navikai gali sąlygoti eritrocitozès, sunkinančios paciento būklę, atsiradimą, todèl svarbu tinkamai gydyti šias ligas.

3. Eritrocitozè gali komplikuoti paciento būklę, todèl svarbu laiku ją nustatyti ir gydyti. Ši būklè gali daryti ịtaką miokardo infarktui, širdies nepakankamumui bei klinikinei mirčiai jauname amžiuje pasireikšti.

\section{Literatūra}

1. Lee G, Arcasoy MO. The clinical and laboratory evaluation of the patient with erythrocytosis. European Journal of Internal 
Medicine 2016;26(5):297-302.

https://doi.org/10.1016/j.ejim.2015.03.007

2. Jang G, Choi DR, Jung HA, Kim J-H, Kim JH. et al. Analysis of patients with erythrocytosis in a single center: comparison between polycythemia vera and non-polycythemia vera. IntJClinExpMed 2016;9(2):4599-4604.

3. Tefferi A, Barbui T. Polycythemia vera and essential thrombocythemia: 2015 update on diagnosis, risk-stratification and management. Am J Hematol 2015; 90(2):162-173.

https://doi.org/10.1002/ajh.23895

4. Griesshammer M, Gisslinger H, Mesa R. Current and future treatment options for polycythemia vera. Ann Hematol 2015; 94(6):901-910.

https://doi.org/10.1007/s00277-015-2357-4

5. Galeas JN, Tegla C, Sukrithan V, Verma A, Goel S. Cardiovascular accidents and increased hemoglobin: secondary erythrocytosis compared to primary polycythemia vera. Blood 2015;126(23):5186.

6. Spivak JL. Polycythemia Vera. CurrTreatOptionsOncol 2018;19(2):12.

https://doi.org/10.1007/s11864-018-0529-x

7. McMullin MF. Secondary erythrocytosis. Hematology 2014; 19(3):183-184.

https://doi.org/10.1179/1024533214Z.000000000263

8. Moulard O, Mehta J, Fryzek J, Olivares R, Iqbal U, Mesa RA. Epidemiology of myelofibrosis, essential thrombocythemia, and polycythemia vera in the European Union. European Journal of Haematology 2014; 92(4):289-297.

https://doi.org/10.1111/ejh.12256

9. Giri S, Mehta KD, Bhatt VR. Secondary polycythemia and the risk of venous thromboembolism (vte) among hospitalized patients in the United States. Blood 2016;128(22):1427.

10. Thiele J, Kvasnicka HM. The 2008 WHO diagnostic criteria for polycythemia vera, essential thrombocythemia, and primary myelofibrosis. Curr Hematol Malig Rep 2009; 4(1):33-40.

https://doi.org/10.1007/s11899-009-0005-6

11. Nadeem O, Gui J, Ornstein DL. Prevalence of venous thromboembolism in patients with secondary polycythemia. Clin Appl Thromb Hemost 2013; 19(4):363-6.

https://doi.org/10.1177/1076029612460425

12. Tefferi A. Diagnostic approach to the patient with polycythemia. In: Schrier SL, ed. Up-to-Date [database on the Internet]. Waltham (MA): UpToDate; 2018 [cited 18 Apr 2018]. Available from: http://www.uptodate.com.
13. Singh GV, Prasad R, Kant S, Kumar S, Verma N, Prakash V. et al. Effects of pulmonary rehabilitation on secondary polycythemia in stable chronic obstructive pulmonary disease: A pilot study. International Journal of Clinical and Experimental Physiology 2014; 1(2):157-160.

https://doi.org/10.4103/2348-8093.137420

14. Assi TB, Baz E. Current applications of therapeutic phlebotomy. Blood Transfus. 2014; 12(1):75-83.

15. Bulbul A, Araujo-Mino EP, Huber M, Bautista A, Thein KZ. et al. Serious cardiovascular events and clinical outcomes in secondary polycythemia: efficacy of conventional phlebotomy and proposed hematocrit target. Blood 2017;130(1):4751.

16. Podoltsev NA, Zhu M, Zeidan A, Wang R, Davidoff AJ. et al. The impact of phlebotomy and hydroxyurea on survival and risk of thrombosis among older patients with polycythemia vera. Blood 2017;130(1):354.

\section{A CASE REPORT OF A PATIENT WITH ERYTHROCYTOSIS AND CHRONIC HEART FAILURE}

A.Neniškienė, E.Taparauskienė, N.Taparauskaitė

Key words: erythrocytosis, secondary erythrocytosis, polycythemia vera.

Summary

Erythrocytosis is a condition in which red blood cell count is elevated, hemoglobin is $>165 \mathrm{~g} / \mathrm{l}$ in women and $>185 \mathrm{~g} / 1$ in men and hematocrit is $>48 \%$ in women and $>52 \%$ in men. Erythrocytosis is classified as relative or absolute and primary or secondary condition. It can develop secondary to congenital and acquired heart defects, pulmonary and renal diseases, oncologic diseases and aggravates the patient's medical condition. Erythrocytosis can increase risk of arterial and venous thrombosis, heart failure and other conditions, therefore early diagnosis and treatment of this condition is necessary.

We present a clinical case of a 34-year-old male who was admitted to the hospital with clinically suspected thrombophlebitis or erysipelas. The patient had a myocardial infarction a year ago and was diagnosed with chronic heart failure. A complete blood count revealed an increase in red blood cells, hemoglobin and hematocrit levels, therefore erythrocytosis was diagnosed. It was found out that erythrocytosis had been diagnosed a year ago but the patient had not been taking any medications for the condition. Secondary erythrocytosis was suspected due to underlying heart condition.

Correspondence to: editatap@gmail.com

Gauta 2018-03-18 